\title{
Factors Affecting the Wisdom of Counselors: Perceptions of Indonesian Pre-service Counselors
}

\author{
Herdi Herdi ${ }^{12 *}$, Sunaryo Kartadinata ${ }^{3}$, Agus Taufiq ${ }^{3}$ \\ ${ }^{1}$ Department of Guidance and Counseling, Faculty of Education, Universitas Negeri Jakarta, \\ Rawamangun Muka Street, East Jakarta, Special Capital Region of Jakarta, Indonesia 13220 \\ ${ }^{2}$ Department of Guidance and Counseling, Postgraduate School, Universitas Pendidikan Indonesia, \\ Dr. Setiabudi Street No. 229, Bandung, West Java, Indonesia 40154 \\ ${ }^{3}$ Department of Educational Psychology and Counseling, Faculty of Education, Universitas Pendidikan Indonesia, \\ Dr. Setiabudi Street No. 229, Bandung, West Java, Indonesia 40154 \\ *corresponding author, e-mail: herdi@unj.ac.id
}

Article received: May 1 ${ }^{\text {st }} 2019$; revised: August $23^{\text {rd }} 2019$; accepted: November $2^{\text {nd }} 2019$

\begin{abstract}
Early theoretical and empirical studies have recommended scholars to explore the factors affecting wisdom of counselors. To enact this void, the present study explores the factors affecting wisdom from the perspectives of Indonesian pre-service counselors (henceforth, participants). This study employed survey design to capture the participants' perceptions. Participants involved in this study were 517 sixth semester pre-service counselors from eleven Guidance and Counseling Departments in Indonesia. Data were collected using questionnaire of Counselor Wisdom Antecedents Scale in the form of Likert five-level scale. The data were then analyzed using descriptive statistics and exploratory factor analysis. The findings captured that there are six factors affecting wisdom of counselor from the perspectives of Indonesian pre-service counselors, namely: (1) social interaction and learning from experiences, (2) values and personality, (3) personal attributes, (4) meta-cognitive skills (critical and depth thinking skills), (5) context-facilitative, and (6) expertise/professionality. The results of this study recommend that counselor educators in the counseling education and supervision programs consider and optimize these factors to develop the wisdom of pre-service counselors.
\end{abstract}

Keywords: counselor education and supervision; factors affecting wisdom; guidance and counseling; pre-service counselor; wisdom

\begin{abstract}
Abstrak: Kajian teoretik dan empirik terdahulu merekomendasikan untuk mengeksplorasi berbagai faktor-faktor kearifan konselor. Tujuan penelitian ini adalah mengeksplorasi berbagai faktor-faktor kearifan konselor menurut pandangan calon konselor Indonesia. Penelitian menggunakan metode deskriptif jenis survei. Partisipan penelitian berjumlah 517 calon konselor semester keenam dari sebelas Departemen Bimbingan dan Konseling di Indonesia yang dipilih menggunakan teknik two stage random sampling. Pengumpulan data menggunakan kuesioner Skala Faktor-faktor Kearifan Konselor yang berbentuk skala lima jenjang. Teknik analisis data menggunakan statistik deskriptif dan analisis faktor eksploratoris. Hasil penelitian menunjukkan terdapat enam faktor kearifan konselor menurut pandangan calon konselor Indonesia, yaitu: (1) interaksi sosial dan belajar dari pengalaman; (2) nilai-nilai dan kepribadian; (3) atribut pribadi; (4) kecakapan metakognitif; (5) konteks-fasilitatif; dan (6) kepakaran. Implikasinya, pendidik konselor dalam program pendidikan dan supervisi konselor perlu memerhatikan dan mengoptimalkan keenam faktor tersebut untuk mengembangkan kearifan calon konselor konselor.
\end{abstract}

Kata kunci: pendidikan dan supervisi konselor; faktor-faktor yang memengaruhi kearifan; bimbingan dan konseling; calon konselor; kearifan

How to cite: Herdi, H., Kartadinata, S., \& Taufiq, A. (2019). Factors Affecting the Wisdom of Counselors: Perceptions of Indonesian Preservice Counselors. Jurnal Kajian Bimbingan dan Konseling, 4(4), 122-133. https://doi.org/10.17977/um001v4i42019p122 


\section{INTRODUCTION}

Counselor's wisdom is one of the most essential and appealing issues to be studied in the context of a pluralistic and multicultural society. In counseling, wisdom plays a crucial role as the fundamental quality of personality and the ultimate competence of effective multicultural counselors (Hanna, Bemak, \& Chung, 1999; Hanna \& Ottens, 1995; Osterlund, 2014, 2016; Phan, Rivera, Volker, \& Maddux, 2009). The counselor's wisdom is also seen as important and can influence the effectiveness and efficacy of counseling (Germer \& Siegel, 2012). In multicultural counseling, wisdom is defined as "a set of specific cognitive and affective traits that are directly related to the ownership and development of life skills and understanding needed for a better life, fulfilment of life needs, effective adjustments, and insights on the nature of self, other people, environment, and interpersonal interactions" (Hanna et al., 1999; Hanna $\&$ Ottens, 1995). The wisdom of multicultural counselors includes cognitive and affective dimensions and awareness. Cognitive dimensions include dialectical reasoning, efficient coping skills, tolerance of ambiguity, sharpness of view, problem finding and alleviation, and metacognition. Meanwhile, affective and awareness dimensions include empathy, concern, feeling recognition, de-automation, and ingenuity.

In order to become an effective multicultural counselor and multicultural clinical psychotherapist, wisdom is seen as more important than intelligence (Hanna et al., 1999; Levitt \& Piazza-Bonin, 2016). A study found that $14 \%$ of multicultural counseling competencies are influenced by the counselor's own wisdom (Phan et al., 2009). Various studies report that wisdom is a personal characteristic of an effective counselor, contributing significantly between 5-12\% of the counseling outcomes (Green, Barkham, Kellett, \& Saxon, 2014; Laska, Smith, Wislocki, Minami, \& Wampold, 2013; Nissen-Lie, Havik, Høglend, Monsen, \& Rønnestad, 2013; Owen \& Hilsenroth, 2014; Saxon \& Barkham, 2012) the recovery rate of counselee in individual counseling ranges from 23.5 to $95.6 \%$ (Saxon \& Barkham, 2012). Conversely, multicultural counselors who only have intelligence without wisdom cannot protect themselves and will only be trapped into "foolishness" behaviour as opposed to "wise" behavior, namely unrealistic optimism, egocentrism, invulnerability, omnipotence, and omniscience (Aczel, 2019; Sternberg, 2005, 2019; Sternberg, Reznitskaya, \& Jarvin, 2007) which can jeopardize and frustrate multicultural counseling processes, alliances and outcomes. Ineffective counselors proved to contribute $12.6 \%$ to the dropout from the counseling session and $10.1 \%$ decline in the psychological well-being of the counselee (Saxon, Barkham, Foster, \& Parry, 2017).

Expert belief that wisdom is a form of virtue in counseling that develops dynamically and can be developed in the education and supervision of counselors (Tukiainen, 2010). Theoretical and empirical studies of the factors that influence wisdom in other fields have been carried out by experts and researchers in the international world. Experts who are members of the Berlin Wisdom Paradigm (Baltes, Glück, \& Kunzmann, 2002; Kunzmann \& Baltes, 2005; Stange \& Kunzmann, 2008; Staudinger, 1999; Staudinger \& Glück, 2011) grouped factors that influence wisdom into (1) context-facilitative factors, such as age, gender, social interactions, education, religion, and culture, (2) expertise factors, including: mentors/role models, experiences of sustainable practice, professional education and training, and life experience, and (3) personal factors, including: intelligence, personality traits, emotional skills, and motivation. Laypeople conceptions (Glück \& Bluck, 2011) report that wisdom is influenced by positive and negative experiences, learning from wise people, experiences facing negative events, studying philosophy, confronting death, confronting uncertainty, growing old, religious/spiritual experiences, and following spiritual guidance gradually. Meanwhile, other research found eight facilitative conditions that influence wisdom according to the views of educators who were nominated wisely, namely: work experience, life experience, social interactions, observation, education in the family, professional development, religion, and reading (Chen, $\mathrm{Wu}, \mathrm{Cheng}, \&$ Hsueh, 2011). This means that participants' backgrounds can cause a variety of views about the factors that influence wisdom.

On the other hand, studies of the factors that influence the counselor's wisdom the perspectives of pre-service counselors are still scant. Thereby, this study can contribute to develop the wisdom from the perspectives of pre-service counselors in the education program and counselor supervision in Indonesia. Based on this rationale, this research is focused on the exploration of the factors that influence the wisdom of counselors from the perspectives of Indonesian pre-service counselors. The research question posed is: What factors influence the wisdom of counselors from the perspective of Indonesian preservice counselors? 


\section{METHOD}

This study employed survey design to explore various facts, opinions, attitudes, and certain behaviors factors that influence the wisdom of counselors according to the Indonesian pre-service counselors' perspections. Participants involved were 517 Indonesian pre-service counselors who were sixth semester students from eleven Department of Guidance and Counseling in Indonesia. They were selected using a two stage random sampling technique. The characteristics of the participants were presented in table 1 . Several aspects were highlighted such as the column on religious affiliation, $M$ = male $; \mathrm{W}=$ Woman; $\mathrm{I}=$ Islam; $\mathrm{CC}=$ Catholic Christianity; $\mathrm{PC}=$ Protestant Christianity; $\mathrm{H}=$ Hindu.

Data in this study were collected using the Skala Faktor-faktor Kearifan Konselor (Counselor Wisdom Factor Scale) (SAKK) developed by researchers. This scale was developed based on the construct of the Berlin Wisdom Paradigm theory (Baltes et al., 2002; Kunzmann \& Baltes, 2005; Stange \& Kunzmann, 2008; Staudinger, 1999; Staudinger \& Glück, 2011) and Laypeople conceptions (Glück \& Bluck, 2011). This scale measures 28 counselor wisdom factors, namely: religion, age, ethnicity, educational context (level and educational institutions), social interactions, professional training, sustainable practices, counseling competence, studying philosophy, learning dialectic thinking, learning using the Socratic dialogue method, experiential learning; learning through self-awareness techniques, meditation practice, life experience, role models, transformation of experience, learning to deal with uncertainty, spiritual guidance, attend the death ceremony, gender, intelligence, personality, motivation, value orientation, worldviews, and moral scales. SAKK is in the form of a rating scale with five levels, namely: $1=$ highly irrelevant, $2=$ not relevant, $3=$ quite relevant, $4=$ relevant, and $5=$ very relevant.

The analysis of instrument quality (validity and reliability) was carried out as a prerequisite for obtaining valid research data. The results of the item validity analysis using item-total correlation showed that all items are valid with a index of rit $=.497-0.624$. The reliability analysis results using Alpha Cronbach obtained .909 (very high). That is, instruments are feasible to use to collect research data.

The data collection was carried out by using a paper and pencil questionnaire by visiting pre-service counselors in eleven Department of Guidance and Counseling according to the schedule agreed by the researcher, the Chair of the Department, and participants. The researchers asked for willingness and

Table 1. Research Participants

\begin{tabular}{|c|c|c|c|c|c|c|c|c|c|c|}
\hline \multirow{3}{*}{ No. } & \multirow{3}{*}{ Institution } & \multicolumn{8}{|c|}{ Demography } & \multirow{3}{*}{ Total } \\
\hline & & \multicolumn{2}{|c|}{ Sex } & \multicolumn{2}{|c|}{ Age } & \multicolumn{4}{|c|}{ Religion } & \\
\hline & & $\mathbf{M}$ & $\mathbf{W}$ & $\begin{array}{l}\leq 20 \\
\text { Years }\end{array}$ & $\begin{array}{l}>20 \\
\text { Years }\end{array}$ & $\mathbf{I}$ & $\mathbf{C C}$ & PC & $\mathbf{H}$ & \\
\hline 1 & Universitas Negeri Semarang (UNNES) & 7 & 33 & 14 & 26 & 40 & 0 & 0 & 0 & 40 \\
\hline 2 & Universitas Negeri Yogyakarta (UNY) & 10 & 54 & 23 & 41 & 59 & 0 & 5 & 0 & 64 \\
\hline 3 & Universitas Negeri Malang (UM) & 17 & 34 & 6 & 45 & 46 & 2 & 2 & 1 & 51 \\
\hline 4 & Universitas Negeri Jakarta (UNJ) & 13 & 59 & 33 & 39 & 69 & 0 & 3 & 0 & 72 \\
\hline 5 & Universitas Negeri Makassar (UNM) & 15 & 53 & 27 & 41 & 67 & 1 & 0 & 0 & 68 \\
\hline 6 & $\begin{array}{l}\text { Universitas Pendidikan Ganesha } \\
\text { (UNDIKSHA) }\end{array}$ & 6 & 22 & 4 & 24 & 6 & 0 & 0 & 22 & 28 \\
\hline 7 & $\begin{array}{l}\text { Universitas Muhammadiyah Prof. Dr. } \\
\text { Hamka (UHAMKA) }\end{array}$ & 18 & 40 & 22 & 36 & 58 & 0 & 0 & 0 & 58 \\
\hline 8 & Universitas Ahmad Dahlan (UAD) & 33 & 47 & 22 & 58 & 80 & 0 & 0 & 0 & 80 \\
\hline 9 & Universitas Katolik Indonesia Atmajaya & 5 & 16 & 0 & 21 & 1 & 15 & 5 & 0 & 21 \\
\hline 10 & Universitas Kristen Indonesia (UKI) & 4 & 7 & 2 & 9 & 0 & 0 & 11 & 0 & 11 \\
\hline \multirow[t]{2}{*}{11} & Universitas Sanata Dharma (USD) & 7 & 17 & 6 & 18 & 1 & 16 & 7 & 0 & 24 \\
\hline & Total & 135 & 382 & 159 & 358 & 427 & 34 & 33 & 23 & 517 \\
\hline
\end{tabular}


submitted a guarantee of data confidentiality to the participants before filling out the SAKK. Participants were then asked to fill in SAKK according to the filling instructions. After the data were collected, the data were then verified, processed, and analyzed.

Descriptive statistical analysis and exploratory factor analysis (EFA) were used to analyze the collected data (average and standard deviation) and. In this study, the EFA was used to explore and extract factors that influence the wisdom of counselors from the perspective of pre-service Indonesian counselors.

\section{RESULTS}

The results showed that there were 28 factors affecting the wisdom of counselors with an average score ranging from 2.8-4.6 on a scale of 1-5. The participants rated 17 factors as highly relevant for developing wisdom with an average score ranging from 4.1-4.6. The seventeen factors are: personality, counseling experience, motivation, social interactions, learning from wise people (counselor educators, mentors, role models, parents), professional training, learning through experience (the experiential learning), worldviews, learn from life experiences, intelligence, moral scales, experience transformation (internalization, integration, and reflection of experience), counseling competence, level of education, religion, value orientation, and learning through self-awareness techniques.

Table 2. Factors Affecting the Wisdom of Counselors based on Indonesian Pre-service Counselors

\begin{tabular}{llcc}
\hline No. & Factors Affecting the Wisdom of Counselors & M & SD \\
\hline 1 & Personality & 4.6 & .6 \\
2 & Counseling experience & 4.5 & .7 \\
3 & Motivation & 4.4 & .7 \\
4 & Profesional development & 4.4 & .8 \\
5 & Learning from wise people & 4.4 & .7 \\
6 & Social interaction & 4.4 & .7 \\
7 & Intelligence & 4.3 & .7 \\
8 & Worldviews & 4.3 & .7 \\
9 & Moral reasoning & 4.3 & .7 \\
10 & Counseling competence & 4.3 & .8 \\
11 & Learning from experiences (ELT) & 4.3 & .7 \\
12 & Learning from life experiences & 4.3 & .7 \\
13 & Internalization, integration, reflective experience & 4.3 & .7 \\
14 & Religion & 4.2 & .7 \\
15 & Value orientation & 4.2 & .8 \\
16 & Level of education & 4.2 & .8 \\
17 & Learning from self-awareness & 4.1 & .8 \\
18 & Education institution & 4.0 & .9 \\
19 & Learning to deal with uncertainty & 3.9 & .8 \\
20 & Learning using Dialog Socratic method & 3.8 & .8 \\
21 & Learning to employ dialectic thinking & 3.7 & .8 \\
22 & Doing meditation & 3.7 & .9 \\
23 & Age & 3.6 & .9 \\
24 & Learning philosophy & 3.6 & .9 \\
25 & Spiritual counseling & 3.5 & 1.0 \\
26 & Ethnic & 3.4 & 1.1 \\
27 & Sex & 3.1 & 1.1 \\
28 & Attending burial ceremony & 2.8 & 1.2 \\
\hline & & \\
\hline
\end{tabular}


The participants also assessed ten relevant factors in affecting the development of counselor's wisdom with an average score ranging from 3.5-4.0. The ten factors are: educational institutions, learn to deal with uncertainty, learn to use the Socratic dialogue method, meditation practice, learning dialectic thinking, studying philosophy, getting older, gradual spiritual guidance (e.g., Sufi traditions), ethnicity, and gender. Meanwhile, the factor of attending the burial ceremony was considered quite relevant in affecting the development of the counselor's wisdom. Detailed research results are presented in table 2 . In table 2, M is the means, and SD is the standard deviation.

In this study, EFA was also carried out using the Principal Component Analysis (PCA) extraction method of PCA and orthogonal rotation (varimax) to summarize 28 factors into several factors of the counselor's wisdom. Verification of the adequacy of the sample is done through the Kaiser-Meyer-Olkin (KMO) test, while the correlation test between items is carried out using the Barlett's test of Sphericity. The test results show a KMO value of .904 , which means great because it far exceeds the minimum

Tabel 3. EFA Test Result of Indonesian Pre-service Counselors' Perceptions of Factors Affecting Counselors' Wisdom

\begin{tabular}{|c|c|c|c|c|c|c|}
\hline \multirow{2}{*}{ Factors of Counselors' Wisdom } & \multicolumn{6}{|c|}{ Anteseden } \\
\hline & 1 & 2 & 3 & 4 & 5 & 6 \\
\hline Social interaction & .722 & & & & & \\
\hline Learning from life experiences & .694 & & & & & \\
\hline Experience transformation & 644 & & & & & \\
\hline Learning from self-awareness technique & .599 & & & & & \\
\hline Experiential learning (ELT) & .591 & & & & & \\
\hline Learning from wise men & .553 & & & & & \\
\hline Learning from uncertainty & .515 & & & & & \\
\hline Values & & .725 & & & & \\
\hline Motivation & & .720 & & & & \\
\hline Life views & & .672 & & & & \\
\hline Personality & & 610 & & & & \\
\hline Moral reasoning & & .593 & & & & \\
\hline Sex & & & .802 & & & \\
\hline Age & & & .719 & & & \\
\hline Ethnic & & & .648 & & & \\
\hline Attending burial ceremony & & & .538 & .472 & & \\
\hline Spiritual guidance & & & .460 & .429 & & \\
\hline \multicolumn{7}{|l|}{ Religion } \\
\hline Learning philosophy & & & & .757 & & \\
\hline Learning dialogic thinking & & & & .728 & & \\
\hline Doing Meditation & & & & .527 & & -.0401 \\
\hline Learning using Socratic dialogue & & & & .481 & & \\
\hline Professional development & & & & & .762 & \\
\hline Educational institution & & & & & 639 & \\
\hline Intelligence & & .435 & & & .536 & \\
\hline Level of education & & & & & .433 & .407 \\
\hline Counseling competence & & & & & & .713 \\
\hline Working experiences & & & & & .439 & .539 \\
\hline Value of Eigen & 8.47 & 2.38 & 1.64 & 1.38 & 1.20 & 1.09 \\
\hline$\%$ Variance & 30.26 & 8.48 & 5.85 & 4.92 & 4.29 & 3.91 \\
\hline
\end{tabular}


acceptable value of .5 (Field, 2009; Kaiser, 1974). The result of Barlett's Test of Sphericity $\chi 2$ (517) = 5530.517; $\mathrm{p}<.001$ ) indicated that the correlation between items is large enough and sufficient to carry out PCA analysis. This means that the data is sufficient for the EFA to test the wisdom factors in the view of prospective Indonesian counselors.

EFA test results using the PCA extraction method and orthogonal rotation (varimax) obtained six factors of wisdom counselors who have an Eigen value $>1$ with a total variance obtained by $57.70 \%$. Variance that can be explained by factors 1 is $30.26 \%$, factors 2 of $8.48 \%$, factors 3 of $5.85 \%$, factors 4 are $4.92 \%$, factors 5 equal to $4.29 \%$, and factors 6 were $3.91 \%$. Scree plots show inflection to maintain justification for six antecedents. Considering the large sample size and the convergence of the Scree Plots and Eigenvalue criteria, then 28 factors can be assigned to six factors for the counselor's wisdom in the view of prospective Indonesian counselors.

Table 3. shows the factor load after rotation. Factors that are grouped on the same factor are made into one main factor. In this test, there was one factor that was removed because it had a factor load of $<.40$, that factor was religion. In addition, there are six factors that experience cross-loading, namely: attending a death ceremony, spiritual guidance gradually, meditation practice, intelligence, level of education, and counseling experience.

Table 3. presents six factors for the counselor's wisdom according to the views of Indonesian preservice counselors. The naming of these factors refers to the results of theoretical studies and relevant empirical findings. The first factor is called social interaction and learning from experience, which consists of social interaction, learn from life experiences, experience transformation (reflection, internalization, integration of experience), learning through self-awareness techniques, experiential learning, learn from wise people, and learning to deal with uncertainty. The second factor is called values and personality, which include values, motivation, and worldviews, personality, and moral scales. The third factor, called personal attributes, includes gender, age, ethnicity, attending the burial ceremony, and gradual spiritual guidance. The fourth factor is called metacognitive skills (critical and deep thinking) which consist of learning philosophy, learning dialectic thinking, meditation practice, and learning by the Socratic dialogue method. The fifth factor is called facilitative context which consists of: professional training; educational institutions, intelligence, and education level. The sixth factor is called expertise (professionalism), including level of education, counseling competence and counseling experience.

\section{DISCUSSION}

Geared under an implicit theoretical approach, this study found six of the 28 factors that influence the wisdom of counselors from the perspective of prospective Indonesian counselors. The six factors are social interaction and learning from experience, values and personality, personal attributes, metacognition, context-facilitative, and expertise (professionalism). The results of this study confirm the Berlin Wisdom Paradigm theory (Baltes et al., 2002; Stange \& Kunzmann, 2008; Staudinger, 1999; Staudinger \& Glück, 2011) that factors (antecedents) influence wisdom; include: (1) context-facilitative factors, such as: age, gender, social interactions, education, religion, and culture, (2) expertise factors, including mentors/role models, experience of ongoing practice, professional education and training, and life experience, and (3) personal factors, namely: intelligence, personality traits, emotional skills, and motivation. The results of this study also confirm the Laypeople conceptions study (Glück \& Bluck, 2011) which reports that wisdom is influenced by positive and negative experiences, learning from wise people, experiences negative events, studying philosophy, confronting death, confronting uncertainty, growing old, religious/spiritual experiences, and following spiritual guidance gradually.

The results of the study also support previous empirical findings about facilitative conditions that influence wisdom according to the views of educators who are nominated wisely, namely: work experience, life experience, social interaction, observation, education in the family, professional development, religion, and reading (Chen et al., 2011). This study also confirms previous findings about the factors that influence the wisdom of counselors from the perspective of prospective ethnic Javanese counselors, as well as the consensus of counselors and counselor educators (Herdi, Kartadinata, \& Taufiq, 2018a, 2018b, 2018c; Herdi, Kartadinata, \& Taufiq, 2017). 


\section{Social Interaction and Learning from Experiences}

Factors of social interaction and learning from experience include social interaction, learning from life experiences, experience transformation (reflection, internalization, and experience integration), learning through self-awareness techniques, experiential learning, learning from wise people, and learning to deal with uncertainty. The results showed that $30.26 \%$ of social interaction factors and learning from experience contributed to the development of the counselor's wisdom in the view of Indonesian pre-service counselors. The results of this study are relevant to the opinions of experts and previous findings. A meta-analysis study reports that social interaction and mentorship/role models are important predictors of wisdom (Baltes et al., 2002; Baltes \& Staudinger, 2000; Kunzmann \& Baltes, 2005; Stange \& Kunzmann, 2008; Staudinger, 1999). Recent studies using the Social Ecological Approach also found that wisdom can be developed through social interactions and transactions (Igarashi, Levenson, \& Aldwin, 2018). This is because the concept of wisdom comes from mutual agreement (Staudinger \& Baltes, 1996) which often manifests itself in social situations (Jeste \& Oswald, 2014; Montgomery, Barber, \& McKee, 2002) and is aimed at achieving public benefit, social harmony and peace. In the tradition of Sufism also emphasized the importance of the role of a mentor (sheikh and dervish) in guiding the murshid to develop and reach the level of ma'rifat (Frager, 2013).

A study of the Experience Corps model reports that wisdom can be activated through experience, reflection, and dialectics in intergenerational social interactions - counselor educators and prospective counselors (Parisi et al., 2009). Through mentorship, counselor educators can formulate alternative and interesting solutions to reflect prior knowledge and experience so as to be able to consider the complexities of life in a more comprehensive and meaningful way. Counselor educators can be role models who are capable of reflective and wise thinking. If wisdom develops and can be developed throughout life, there is a possibility that early life experiences will help in developing the quality of wisdom.

An empirical study found that the key factors that influence the development of wisdom, is learning from experience through reflection, integration, and transformation of experience (Brown, 2004). The development of wisdom requires transcendence and projections that can be obtained through selfawareness, self-testing, and reflection on behavior, interactions, and lifelong experiences (Ardelt, 2009; Ardelt \& Oh, 2010; Levitt, 1999; Staudinger, 1999). The results of this study are also relevant to the research findings which state that the factors that influence wisdom are: learning from life experiences, social interactions, and education in the family (Chen et al., 2011), life experience, mentorship, and parenting as a context-facilitative factor (Baltes et al., 2002; Baltes \& Staudinger, 2000; Kunzmann \& Baltes, 2005; Stange \& Kunzmann, 2008), mentorship in overcoming life problems (Baltes \& Staudinger, 2000; Staudinger, 1999; Staudinger \& Glück, 2011). Results of a meta-analysis study (Baltes \& Staudinger, 2000) found that $26 \%$ of wisdom variability was influenced by general life experience and specific professional experience. Similar research shows that the learning factor from experience contributes $46.7 \%$ to the wisdom of prospective counselors from the counselor's perspective (Herdi et al., 2018c), 28.8\% from the perspective of prospective ethnic Javanese counselors (Herdi et al., 2017), and an average of 4.5 on a scale of 5 from the perspective of counselor educators (Herdi et al., 2018b).

In order to become a wise counselor, pre-service counselors need to be given the opportunity to reflect, ask questions, internalize, and integrate their personal and professional experiences (Hanna et al., 1999). Empirical studies show the transformation of experience (reflection, internalization, and integration of experience) and self-awareness contribute $28.94 \%$ to the development of counselor's wisdom from the counselor's perspective (Herdi et al., 2018a). Wisdom depends on the ability of prospective counselors to integrate and reflect lifelong experiences and utilize these experiences in everyday life (Baltes \& Staudinger, 2000) as well as using it in counseling practices in authentic scenes.

\section{Values and Personality}

The values and personalities given are values, motivation, life judgments, personality, and moral scales. The results showed that $8.48 \%$ of values and personality contributed to the development of the counselor's wisdom in the view of prospective Indonesian counselors. Theoretical and empirical studies of the findings of cultural values (Le, 2008), values of openness (Le, 2011), openness to experience (Mickler \& Staudinger, 2008; Staudinger, Dörner, \& Mickler, 2005), and personality (affective, value 
orientation, motivation, and inter-personality) (Kunzmann \& Baltes, 2003) is an ontogenesis factor of wisdom. Personality (openness to experience) contributes $21 \%$ to wisdom-related knowledge and scales (Baltes \& Staudinger, 2000) and 14\% of wisdom-related performance (Staudinger, Maciel, Smith, \& Baltes, 1998). Another study reported that personality factors (need of nurturance) had a significant positive correlation in the strong category $(\mathrm{r}=.68)$ and contributed $46.7 \%$ to the wisdom of prospective counselors (Herdi et al., 2018c), 28.8\% according to the view of prospective ethnic Javanese counselors (Herdi et al., 2017), and an average of 4.5 on a scale of 5 according to the counselor educator's view (Herdi et al., 2018b).

\section{Personal Attributes}

The results showed that $5.85 \%$ of personal attributes (gender, age, ethnicity) and spiritual guidance contribute to wisdom according to the views of prospective Indonesian counselors. Empirical studies show that gender and age have a significant positive effect on overall wisdom and on the cognitive, reflective, and affective dimensions (Cheraghi, Kadivar, Ardelt, Asgari, \& Farzad, 2015). Other studies (Hollingworth, Sánchez-Escobedo, Graudina, Misiuniene, \& Park, 2013) indicated that gender contributes $52 \%$ to the variation in wisdom of adolescents aged 15-18 years in Latvia, Lithuania, Mexico, Korea, and the USA. In adolescent boys, $34.7 \%$ of variation in wisdom is explained by factors of personality, responsibility, goal orientation, and creativity. In women, $38.3 \%$ of variation in wisdom is explained by factors of social influence, responsibility, goal achievement, and creativity. Other studies show that specifically women have the highest score on the affective dimension, while men on the cognitive dimension (Ardelt, 2009). Other results also show that men's wisdom experiences are more cognitively oriented and related to professional life, while women's wisdom experiences are related to events in the family, illness, or death (Glück, Strasser, \& Bluck, 2009).

In psychosocial theory, wisdom is seen as the culmination of human development and one of the important positive outcomes of aging (Etezadi \& Pushkar, 2013; Parisi et al., 2009) in old age the virtue of success facing a crisis of integrity against disunity (Erikson \& Erikson, 1998; Erikson, Erikson, \& Kivnick, 1994; Erikson, 1959). This view is supported by the fact that the majority of ordinary people that wise individuals average age above 60 years (Orwoll \& Perlmutter, 1990). A cross-sectional study found that age has a significant positive relationship with wisdom (Pasupathi, Staudinger, \& Baltes, 2001) and showed significant differences in wisdom (affective and reflective dimensions) in the five participant age groups (Asadi, Amiri, Molavi, \& Noaparast, 2011). Middle and late adult individuals have significantly higher wisdom (affective and reflective dimensions) than young adult individuals and students (Ardelt, 2010; Webster, Bohlmeijer, \& Westerhof, 2014; Webster, Westerhof, \& Bohlmeijer, 2012). General wisdom tends to increase with age and experience (Jeste \& Oswald, 2014; Thomas \& Kunzmann, 2013). This fact is in line with the theory of crystalized intelligence that develops dynamically with age.

\section{Religion, Spirituality, and Wisdom}

A meta-analysis study shows that religion/spiritual is one of the context-facilitative factors of wisdom (Kunzmann \& Baltes, 2005) and the source of wisdom concepts (Brezina \& Van Oudenhoven, 2012; Önal, 2010). Empirical studies show that religious affiliation, religious/spiritual experience, and spiritual guidance can gradually influence the development of wisdom in the eyes of the general public (Glück \& Bluck, 2011) and educators who are nominated wisely (Chen et al., 2011).

\section{Metacognition}

Metacognition factors, including: studying philosophy, learning dialectic thinking, meditation practice, and learning with Socratic dialogue. The results showed that $4.92 \%$ of metacognition factors (critical and deep thinking) contributed to the development of counselor's wisdom from the perspective of prospective Indonesian counselors. Previous experts and researchers view that metacognition is one of the main components of wisdom. Counselors with metacognitive skills will have concern for the limitations and estimates of knowledge, awareness of awareness, knowing about knowing, thinking about thinking, and intuitive knowledge (Hanna et al., 1999; Hanna \& Ottens, 1995). Metacognition is also characterized by critical thinking skills that are directly related to wisdom (Barris \& Ruff, 2011). 


\section{Context-Facilitative}

Context-facilitative factors, including: professional training, educational institutions, and education levels. The results showed that in the view of prospective Indonesian counselors $4.29 \%$ contextfacilitative contributed to the development of counselor's wisdom. The results of this study are relevant to expert opinions and previous empirical findings that one of the context-facilitative factors that influence wisdom is education and professional training (Baltes et al., 2002; Baltes \& Staudinger, 2000; Chen et al., 2011; Staudinger, 1999). Education and / or experience have a strategic role in developing wisdom (Frantz, 2014).

Other experts propose and find ways to develop wisdom on campus, through practice, reflection, and integration of practical experience (Brown, 2004). This can be done by creating four facilitative conditions for the development of wisdom, namely: orientation towards learning, experience, interaction with others, and a conducive environment. Even Balance Theory of Wisdom experts suggested the importance of designing and implementing an infused curriculum to develop students' wisdom (Karelitz, Jarvin, \& Sternberg, 2010; Sternberg, 2005, 2019; Sternberg, Jarvin, \& Reznitskaya, 2008; Sternberg, 1998, 2005; Sternberg, Jarvin, \& Grigorenko, 2009).

\section{Expertise}

Expertise factors (professionalism), including: counseling competence and counseling experience. The results showed that in the view of prospective counselors 3.91\% expertise (professionalism) contributed to the development of counselor's wisdom. Expert studies and previous empirical findings also report that expertise factors such as experience of sustainable practice (Kunzmann \& Baltes, 2005; Stange \& Kunzmann, 2008) influence wisdom.

\section{CONCLUSION}

Indonesian pre-service counselors view that there are six factors that influence the counselor's wisdom, namely: (1) social interaction and learning from experience; (2) values and personality; (3) personal attributes; (4) metacognitive skills (critical and deep thinking); (5) context-facilitative; and (6) expertise (professionalism). Suggestions are addressed to various parties involved. First, pre-service counselors are expected to develop personal wisdom by: (1) increasing social interaction and learning from personal experiences and wise people (e.g. counselor educators, counselors, mentors, role models, and wise parents); (2) learning and practicing optimizing metacognitive skills (e.g., studying philosophy and learning dialectic thinking); and (3) follow authentic experience-based education and training to increase expertise (professionalism) in counseling. Secondly, counselor educators in the department of Guidance and Counseling and administrators of the Indonesian Guidance and Counseling Association (Asosiasi Bimbingan dan Konseling (ABKIN)) are expected to provide facilitative educational and supervisory supervision programs for the development of the wisdom of pre-service counselors. The intended counseling education program includes: (1) curriculum content containing content for developing wisdom, both specifically in the counselor's personal development course and integrated in each subject; (2) learning strategies can use experiential learning models in authentic scenes, Socratic dialogue, self-awareness techniques, meditation practice, spiritual guidance gradually; (3) evaluation of learning based on authentic assessment; and (4) counselor educators present themselves as wise individuals and counselors for pre-service counselors, both in the learning process and in everyday life. Third, the researcher is then expected to be able to study the factors that influence wisdom in the view of counselor and counselor educators, examine various variables of wisdom counselor consequences, and develop and test various learning strategies to develop the wisdom of pre-service counselors.

\section{ACKNOWLEDGMENT}

Our sincere thanks are addressed to the Head of Department of Guidance and Counseling on this study, participants involved, and other related parties that contributed to the development of this research project. 


\section{REFERENCES}

Aczel, B. (2019). Low Levels of Wisdom. In R. J. Sternberg \& J. Gluck (Eds.), The Cambridge Handbook of Wisdom (pp. 483-499). Cambridge: Cambridge University Press.

Ardelt, M. (2009). How Similar are Wise Men and Women? A Comparison Across Two Age Cohorts. Research in Human Development, 6(1), 9-26.

Ardelt, M. (2010). Are Older Adults Wiser than College Students? A Comparison of Two Age Cohorts. Journal of Adult Development, 17(4), 193-207.

Ardelt, M., \& Oh, H. (2010). Wisdom: Definition, Assessement, and Its Relation to Successful Cognitive and Emotional Aging. In D. V. Jeste \& C. Depp (Eds.), Successful Cognitive and Emotional Aging (pp. 87-113). Washington, DC: American Psychiatric Publishing, Inc.

Asadi, S., Amiri, H., Molavi, S., \& Noaparast, K. B. (2011). A Cross-Sectional Study of Self Reported Wisdom Development: From Adolescence Through Adulthood. Interdisciplinary Journal of Contemporary Research in Business, 4(2), 482-492.

Baltes, P. B., Glück, J., \& Kunamann, U. (2002). Wisdom: its Structure and Function in Regulating Successful Life Span Development. In C. R. Snyder \& S. J. Lopez (Eds.), The Handbook of Positive Psychology (pp. 327-347). New York: Oxford University Press.

Baltes, P. B., \& Staudinger, U. M. (2000). Wisdom: A Metaheuristic (Pragmatic) to Orchestrate Mind and Virtue Toward Excellence. American Psychologist, 55(1), 122-136.

Barris, J., \& Ruff, J. C. C. (2011). Thoughts on Wisdom and Its Relation to Critical Thinking, Multiculturalism, and Global Awareness. Analytic Teaching and Philosophical Praxis, 31(1), 5-20.

Brezina, I., \& Van Oudenhoven, J. P. (2012). Do National Cultures or Religions Shape Conceptions of Wisdom? Studia Psychologica, 54(4), 299-311.

Brown, S. C. (2004). Learning Across The Campus: How College Facilitates The Development of Wisdom. Journal of College Student Development, 45(2), 134-148.

Chen, L.-M., Wu, P.-J., Cheng, Y.-Y., \& Hsueh, H.-I. (2011). A Qualitative Inquiry of Wisdom Development: Educators' Perspectives. The International Journal of Aging and Human Development, 72(3), 171-187.

Cheraghi, F., Kadivar, P., Ardelt, M., Asgari, A., \& Farzad, V. (2015). Gender As A Moderator of The Relation Between Age Cohort and Three-Dimensional Wisdom in Iranian Culture. The International Journal of Aging and Human Development, 81(1-2), 3-26.

Erikson, E. H., \& Erikson, J. M. (1998). The Life Cycle Completed (Extended Version). WW Norton \& Company. Erikson, E. H., Erikson, J. M., \& Kivnick, H. Q. (1994). Vital Involvement in Old Age. WW Norton \& Company.

Erikson, E. H., (1959). Identity and The Life Cycle: Selected Papers.

Etezadi, S., \& Pushkar, D. (2013). Why are Wise People Happier? An Explanatory Model of Wisdom and Emotional Well-Being in Older Adults. Journal of Happiness Studies, 14(3), 929-950.

Field, A. (2009). Discovering Statistics using SPSS:(and Sex, Drugs and Rock'n'roll) (Vol. 497). Sage.

Frager, R. (2013). Heart, Self, \& Soul: The Sufi Psychology of Growth, Balance, and Harmony. Quest Books.

Frantz, G. (2014). Wisdom: Experience or Education? Psychological Perspectives, 57(1), 1-3.

Germer, C. K., \& Siegel, R. D. (2012). Wisdom and Compassion in Psychotherapy: Deepening Mindfulness in Clinical Practice. Guilford Press.

Glück, J., \& Bluck, S. (2011). Laypeople's Conceptions of Wisdom and Its Development: Cognitive and Integrative Views. Journals of Gerontology Series B: Psychological Sciences and Social Sciences, 66(3), 321-324.

Glück, J., Strasser, I., \& Bluck, S. (2009). Gender Differences in Implicit Theories of Wisdom. Research in Human Development, 6(1), 27-44.

Green, H., Barkham, M., Kellett, S., \& Saxon, D. (2014). Therapist Effects and IAPT Psychological Wellbeing Practitioners (PWPs): A Multilevel Modelling and Mixed Methods Analysis. Behaviour Research and Therapy, 63, 43-54.

Hanna, F. J., Bemak, F., \& Chung, R. C. (1999). Toward a New Paradigm for Multicultural Counseling. Journal of Counseling \& Development, 77(2), 125-134.

Hanna, F. J., \& Ottens, A. J. (1995). The Role of Wisdom in Psychotherapy. Journal of Psychotherapy Integration, 5(3), 195-219. https://doi.org/10.1037/h0101273

Herdi, H, Kartadinata, S., \& Taufiq, A. (2018a). Kearifan Konselor Multibudaya dan Pengembangannya Menurut Konselor. In Konvensi Nasional Bimbingan dan Konseling Ke-XX (pp. 80-91). Pekanbaru: UR Press. 
Herdi, H, Kartadinata, S., \& Taufiq, A. (2018b). Konsensus Pendidik Konselor Tentang Kearifan Konselor Multibudaya dan Pengembangannya. In Konvensi Nasional Bimbingan dan Konseling ke-XX (pp. 10391047). Pekanbaru: UR Press.

Herdi, H, Kartadinata, S., \& Taufiq, A. (2018c). Peran Kepribadian Terhadap Kearifan Calon Konselor Multibudaya. In Konvensi Nasional Bimbingan dan Konseling ke-XX (pp. 392-398). Pekanbaru: UR Press.

Herdi, H., Kartadinata, S., \& Taufiq, A. (2017). Faktor-Faktor yang Mempengaruhi Kearifan Konselor Menurut Perspektif Calon Konselor Etnis Jawa. Jurnal Penelitian dan Evaluasi Pendidikan, 21(2), 162-174.

Hollingworth, L., Sánchez-Escobedo, P., Graudina, L., Misiuniene, J., \& Park, K. (2013). Gender Differences on The Concept of Wisdom: An International Comparison. Gifted and Talented International, 28(1-2), 219-225.

Igarashi, H., Levenson, M. R., \& Aldwin, C. M. (2018). The Development of Wisdom: A Social Ecological Approach. The Journals of Gerontology: Series B, 73(8), 1350-1358.

Jeste, D. V., \& Oswald, A. J. (2014). Individual and Societal Wisdom: Explaining The Paradox of Human Aging and High Well-Being. Psychiatry: Interpersonal and Biological Processes, 77(4), 317-330.

Kaiser, H. F. (1974). An Index of Factorial Simplicity. Psychometrika, 39(1), 31-36.

Karelitz, T. M., Jarvin, L., \& Sternberg, R. J. (2010). The Meaning of Wisdom and Its Development Throughout Life. In R. M. Lerner \& W. F. Overton (Eds.), The Handbook of Life-Span Development. Hoboken, NJ, USA: John Wiley \& Sons, Inc. https://doi.org/10.1002/9780470880166.hlsd001023

Kunzmann, U., \& Baltes, P. B. (2003). Wisdom-Related Knowledge: Affective, Motivational, and Interpersonal Correlates. Personality and Social Psychology Bulletin, 29(9), 1104-1119.

Kunzmann, U., \& Baltes, P. B. (2005). The Psychology of Wisdom: Theoretical and Empirical Challenges.

Laska, K. M., Smith, T. L., Wislocki, A. P., Minami, T., \& Wampold, B. E. (2013). Uniformity of EvidenceBased Treatments in Practice? Therapist Effects in The Delivery of Cognitive Processing Therapy for PTSD. Journal of Counseling Psychology, 60(1), 31-41. https://doi.org/10.1037/a0031294

Le, T. N. (2008). Cultural Values, Life Experiences, and Wisdom. The International Journal of Aging and Human Development, 66(4), 259-281.

Le, T. N. (2011). Life Satisfaction, Openness Value, Self-Transcendence, and Wisdom. Journal of Happiness Studies, 12(2), 171-182.

Levitt, H. M. (1999). The Development of Wisdom: An Analysis of Tibetan Buddhist Experience. Journal of Humanistic Psychology, 39(2), 86-105.

Levitt, H. M., \& Piazza-Bonin, E. (2016). Wisdom and Psychotherapy: Studying Expert Therapists' Clinical Wisdom to Explicate Common Processes. Psychotherapy Research, 26(1), 31-47.

Mickler, C., \& Staudinger, U. M. (2008). Personal Wisdom: Validation and Age-Related Differences of A Performance Measure. Psychology and Aging, 23(4), 787-799.

Montgomery, A., Barber, C., \& McKee, P. (2002). A Phenomenological Study of Wisdom in Later Life. The International Journal of Aging and Human Development, 54(2), 139-157.

Nissen-Lie, H. A., Havik, O. E., Høglend, P. A., Monsen, J. T., \& Rønnestad, M. H. (2013). The Contribution of The Quality of Therapists' Personal Lives to The Development of The Working Alliance. Journal of Counseling Psychology, 60(4), 483-495. https://doi.org/10.1037/a0033643

Önal, M. (2010). Wisdom (Hikmah) as A Holistic Basis for Inter-Religious Education. In International Handbook of Inter-Religious Education (pp. 221-234). Springer.

Orwoll, L., \& Perlmutter, M. (1990). The Study of Wise Persons: Integrating a Personality Perspective. In R. J. Sternberg (Ed.), Wisdom: Its Nature, Origins, and Development (pp. 160-177). Cambridge: Cambridge University Press.

Osterlund, L. C. (2014). Wisdom in The Counseling Relationship. Jesuit Higher Education, 3(2), 74-84.

Osterlund, L. C. (2016). Developing Wisdom in Counselors of The Futurep. Ignatian Pedagogy Applied to Counselor Education and Supervision. VISTAS Online, 1-11.

Owen, J., \& Hilsenroth, M. J. (2014). Treatment Adherence: The Importance of Therapist Flexibility in Relation to Therapy Outcomes. Journal of Counseling Psychology, 61(2), 280-288. https://doi.org/10.1037/a0035753

Parisi, J. M., Rebok, G. W., Carlson, M. C., Fried, L. P., Seeman, T. E., Tan, E. J., ... Piferi, R. L. (2009). Can the Wisdom of Aging Be Activated and Make A Difference Societally? Educational Gerontology, 35(10), $867-879$

Pasupathi, M., Staudinger, U. M., \& Baltes, P. B. (2001). Seeds of Wisdom: Adolescents' Knowledge and Judgment about Difficult Life Problems. Developmental Psychology, 37(3), 351-361. 
Phan, L. T., Rivera, E. T., Volker, M., \& Maddux, C. D. (2009). Wisdom in Multicultural Counseling: The Omitted Ingredient. Interamerican Journal of Psychology, 43(1), 154-161.

Saxon, D., \& Barkham, M. (2012). Patterns of Therapist Variability: Therapist Effects and The Contribution of Patient Severity and Risk. Journal of Consulting and Clinical Psychology, 80(4), 535-546. https://doi. org/10.1037/a0028898

Saxon, D., Barkham, M., Foster, A., \& Parry, G. (2017). The Contribution of Therapist Effects to Patient Dropout and Deterioration in The Psychological Therapies. Clinical Psychology \& Psychotherapy, 24(3), 575-588.

Stange, A., \& Kunzmann, U. (2008). Fostering Wisdom: A Psychological Perspective. In Teaching for Wisdom (pp. 23-36). Springer.

Staudinger, U. M. (1999). Older and Wiser? Integrating Results on The Relationship Between Age and WisdomRelated Performance. International Journal of Behavioral Development, 23(3), 641-664.

Staudinger, U. M., \& Baltes, P. B. (1996). Interactive Minds: A Facilitative Setting for Wisdom-Related Performance? Journal of Personality and Social Psychology, 71(4), 746-762.

Staudinger, U. M., Dörner, J., \& Mickler, C. (2005). Wisdom and Personality. In R. J. Sternberg \& J. Jordan (Eds.), A Handbook of Wisdom: Psychological Perspectives (pp. 191-219). Cambridge: Cambridge University Press.

Staudinger, U. M., \& Glück, J. (2011). Psychological Wisdom Research: Commonalities and Differences in A Growing Field. Annual Review of Psychology, 62, 215-241.

Staudinger, U. M., Maciel, A. G., Smith, J., \& Baltes, P. B. (1998). What Predicts Wisdom-Related Performance? A First Look at Personality, Intelligence, and Facilitative Experiential Contexts. European Journal of Personality, 12(1), 1-17.

Sternberg, R. J. (2005). Foolishness. In R. J. Sternberg \& J. Jordan (Eds.), A Handbook of Wisdom: Psychological Perspectives (pp. 331-352). Cambridge University Press.

Sternberg, R. J. (2019). The Critical Important of Wisdom in The World Today. In R. J. Sternberg \& J. Gluck (Eds.), The Cambridge Handbook of Wisdom (pp. 3-9). Cambridge University Press.

Sternberg, R. J., Jarvin, L., \& Reznitskaya, A. (2008). Teaching for Wisdom Through History: Infusing Wise Thinking Skills in the School Curriculum. In M. Ferrari \& G. Potworowski (Eds.), Teaching for Wisdom (pp. 37-57). Dordrecht: Springer Netherlands. https://doi.org/10.1007/978-1-4020-6532-3_3

Sternberg, R. J., Reznitskaya, A., \& Jarvin, L. (2007). Teaching for Wisdom: What Matters is Not Just What Students Know, But How They Use It. London Review of Education, 5(2), 143-158. https://doi. org/10.1080/14748460701440830

Sternberg, R. J. (1998). A Balance Theory of Wisdom. Review of General Psychology, 2(4), 347-365.

Sternberg, R. J. (2005). Older but Not Wiser? The Relationship Between Age and Wisdom. Ageing International, $30(1), 5-26$.

Sternberg, R. J., Jarvin, L., \& Grigorenko, E. L. (2009). Teaching for Wisdom, Intelligence, Creativity, and Success. Corwin Press.

Thomas, S., \& Kunzmann, U. (2013). Age Differences in Wisdom-Related Knowledge: Does The Age Relevance of The Task Matter? Journals of Gerontology Series B: Psychological Sciences and Social Sciences, 69(6), 897-905.

Tukiainen, A. (2010). Philosophical Counselling As A Process of Fostering Wisdom in The Form of Virtues. Practical Philosophy, 10(1), 48-57.

Webster, J. D., Bohlmeijer, E. T., \& Westerhof, G. J. (2014). Time to Flourish: The Relationship of Temporal Perspective to Well-Being and Wisdom Across Adulthood. Aging \& Mental Health, 18(8), 1046-1056.

Webster, J. D., Westerhof, G. J., \& Bohlmeijer, E. T. (2012). Wisdom and Mental Health Across The Lifespan. Journals of Gerontology Series B: Psychological Sciences and Social Sciences, 69(2), 209-218. 